\title{
Digital Artery Perforator Flap Use in Reconstruction of Fingertip Defects
}

\section{Parmak Ucu Doku Defektlerinde Dijital Arter Perforatör Flebinin Kullanımı}

Alper Ural ${ }^{1}$,

Fatma Bilgen ${ }^{1}$,

Mahmut Durak Ceviz ${ }^{1}$,

Mustafa Ridvan Yanbas ${ }^{1}$,

Mehmet Bekerecioglu ${ }^{1}$

${ }^{1}$ Kahramanmaraş Sütçü Imam University, Department of Plastic, Reconstructive and Aesthetic Surgery, Kahramanmaraş, Turkey

Geliş Tarihi/Received: 18 August 2020

Kabul Tarihi/Accepted: 20 November 2020

Address correspondence to: Alper Ural, Kahramanmaraş Sütçü Imam University, Department of Plastic, Reconstructive and Aesthetic Surgeryy, kahramanmaraş, Turkey e-mail: alper_ural@yahoo.com

\section{ORCID}

Alper Ural

https://orcid.org/0000-0001-8135-6444

Fatma Bilgen

https://orcid.org//0000-0002-2127-3441

Mahmut Durak Ceviz

https://orcid.org/0000-0002-4140-9043

Mustafa Ridvan Yanbas

https://orcid.org/0000-0002-0937-9593

Mehmet Bekerecioglu

https://orcid.org/0000-0002-2422-7272

\begin{abstract}
Öz
Amaç: Parmak ucu defektlerinin rekonstrüksiyonunda dijital arter perforatör flebi kullanarak yapılan rekonstrüksiyonlar ile ilgili deneyimimizi bildirmeyi amaçladık.

Hastalar ve Yöntem: Aralık 2019-Eylül 2020 arasında parmak defektleri nedeniyle ameliyat edilen ve dijital arter perforatör flep ile rekonstrüksiyon yapılan 8 hasta çalışmaya dahil edildi. Hastalar etyoloji, cinsiyet, yaş, komorbidite ve sonuçlar açısından değerlendirildi.

Bulgular: Hastaların ortalama yaşı 43,6 (19-66) idi. 8 flebin 6'sı tam olarak sağ kaldı ve sorunsuz iyileşti. Fleplerin boyutları $20 \times 10 \mathrm{~mm}$ ile $25 \times 20 \mathrm{~mm}$ arasındaydı. Bir flepte kısmi cilt nekrozu yaşanırken 1 flep ise tamamen kaybedildi. Hiçbir hasta soğuk intoleransından veya eklem kontraktüründen şikayetçi değildi. Hastalardan birinde hafif tırnak deformitesi oluştu.

Sonuç: Dijital arter perforatör flebi (DAPF), komorbiditesi olmayan ve sigara içmeyen hastalarda parmak ucu defekti rekonstrüksiyonları için güvenilir ve çok yönlü bir fleptir. Tek aşamalı ameliyat prosedürü, flebi hazırlama kolaylığı, hızlı iyileşme ve dijital arterlerin korunması en önemli avantajlarıdır.
\end{abstract}

Anahtar Kelimeler: Dijital arter perforator flebi, parmak, parmak rekonstrüksiyonu, perforator flep, pulpa defekti, üst extremite

\section{Abstract}

Aim: We aimed to report our experience of a digital artery perforator flap use in fingertip and pulp defects reconstruction.

Patients and Methods: 8 patients underwent reconstruction with digital artery perforator flap for their finger defects were enrolled between December 2019 and September 2020 in the study. The patients were evaluated in terms of etiology, sex, age, comorbidities and outcomes. The size of the flaps ranged from $20 \times 10 \mathrm{~mm}$ to $25 \times 20 \mathrm{~mm}$.

Results: The average age of the patients was 43.6 (range: 19-66) years. 6 of 8 flaps survived completely and healed uneventfully. The size of the flaps ranged from $20 \times 10 \mathrm{~mm}$ to $25 \times 20 \mathrm{~mm} .1 \mathrm{flap}$ was totally lost where as 1 flap had partial skin necrosis. No patients complained of cold intolerance or residual joint contracture. Mild hooked nail deformity occurred in one of the patients.

Conclusions: The DAPF is a reliable and versatile flap for fingertip defect reconstructions in non smoker patients without comorbidities. Single-stage operating procedure, ease of harvest, rapid recovery and preservation of digital arteries are the most important advantages.

Key words: Digital artery perforator flap, pulp defect, finger reconstruction, perforator flap, upper extremity
Cite this article as: Ural A, Bilgen F, Ceviz MD, Yanbas MR, Bekerecioglu M. Digital Artery Perforator Flap Use in Reconstruction of Fingertip Defects. Selcuk Med J 2020;36(4): 343-351

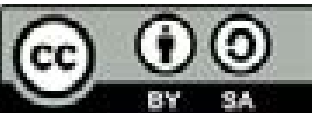

Disclosure: None of the authors has a financial interest in any of the products, devices, or drugs mentioned in this article. The research was not sponsored by an outside organization. All authors have agreed to allow full access to the primary data and to allow the journal to review the data if requested. 


\section{INTRODUCTION}

Fingers are one of the most exposed areas to trauma and fingertip defects are among the most common injuries. Fingertips and pulps are unique structures for both functionality and cosmesis. The main objectives of fingertip and pulp reconstruction can be listed as maintaining functional length, preventing secondary nail deformity and joint stiffness as well as ensuring a sensorial pulp. Reconstruction of the fingertip defects which bone, tendon or joint are exposed are surgically challenging and necessitate durable flaps. Various reconstructive treatment options including local homodigital advancement flaps, cross finger flaps, local island flaps, reverseflow homodigital artery flaps, reverse adipofascial flaps and even microsurgical free flaps have been described for the treatment of injured fingertip and pulp defects (1-5). The digital artery perforator flap (DAPF), first described by Koshima, is still a relatively novel technique to some plastic and reconstructive surgery departments (6). Nevertheless, it seems to be gaining popularity since DAPF technique does not require neurovascular bundle dissection or transection and eliminates a second operation requirement (7). DAPF is an advantageous technique in fingertip and pulp reconstruction for it is less invasive and reliable. We aimed to present our experience and evaluate the results of fingertip defect reconstructions using digital artery perforator flaps.

\section{PATIENTS AND METHODS}

This study was carried out with the approval of the local ethics committee of Kahramanmaras Sutcu Imam University, Faculty of Medicine (Protocol number: 08) and by obtaining written informed consent from all patients. A total of 8 patients who underwent surgery by utilizing digital artery perforator flap in order to reconstruct fingertip defects between December 2019 and September 2020 were enrolled in the study. Drug use, tobacco use, and other comorbid diseases that could compromise wound healing were investigated and recorded. The patients were evaluated in terms of etiology, sex, age, comorbidities and outcomes. Patients that are previously injured on the same finger, multiple-level injury to the same finger and with peripheral arterial disease were excluded. The patients with finger defect diameters $>3 \mathrm{~cm}$ or $<1.5 \mathrm{~cm}$ in size were also excluded. The details are shown in Table 1.

\section{Surgical Technique}

The perfusion of the DAPF is supplied from constant dorsal communicating branches of digital arteries. Venous outflow is provided from the concommitant system surrounding the arterial pedicle. We performed DAPF flap as propeller flap on its perforator in six patients while we transposed DAPF normograde fashion in one patient and used it as an advancement flap in another. DAPF was designed over the dorsal or dorsolateral of the middle or proximal phalanx. The flaps were raised from the more preserved sides of the fingers since the distalmost perforator can be directly injured for its proximity to the trauma zone. It is crucial to elevate the flaps superficial to the digital artery and nerve and perform a dissection plane over paratenon. If DAPF was harvested from the proximal phalanx, we dissected the perforator in a retrograde fashion towards the proper digital artery and aimed to leave about at least 3-4 $\mathrm{mm}$ adipofascial tissue surrounding the pedicle. This adipofascial cuff composed of soft tissue was preserved around the pedicle to minimize venous congestion. When DAPF was harvested from midphalanx, the cuff surrounding the perforator was thinner (Figure 1). However, an exact skeletonization of these tiny calibered vessels were avoided except two cases to prevent any possible perforator injury. We have skeletonized DAPF perforator only in two cases to reduce the tension and ease the mobility and rotation of the flap. The distalmost perforator could be observed under magnification in each case clearly. The Cleland ligament was incised and released when needed. We inset the flap to the defects transposing about $60-120^{\circ}$ in three cases whereas we transposed the flap as propeller and rotated $180^{\circ}$ over its pedicle in three cases. To prevent pedicle compression and postoperative venous congestion, we incised the skin and created a raw surface for the transfer of the pedicle. Then, the flap is sutured to the defect without tension and the donor site was closed using a fullthickness skin graft. Short-arm resting splints were applied for each patient for a week.

\section{RESULTS}

A total of 8 patients (4 females and 4 males) consulted from the department of orthopedics or emergency department who received finger pulp reconstruction utilizing digital artery perforator flaps were included in this study. The etiology of the defects were work related accidents $(n=4)$, home accidents $(n=3)$ and infection $(n=1)$. The average age of the patients was 43.6 (range:19-66) years. Reconstructions were performed under regional or general anesthesia 6 of 8 flaps survived completely 
Table 1. Patient demographics and outcomes

\begin{tabular}{llllcc}
\hline Case & Gender & Age & Digit & Comorbidity/drugs & Outcome \\
\hline 1 & Male & 41 & Index & - & Full recovery \\
2 & Female & 28 & Middle & Asthma & Full recovery \\
3 & Female & 57 & Middle & Index & Rheumatoid Arthritis+Corticosteroid \\
4 & Female & 62 & Middle & Hypertension & Partial necrosis \\
5 & Male & 54 & Index & Full recovery \\
6 & Male & 19 & Index & Maras powder+tobacco & Full recovery \\
7 & Male & 22 & Little & Alzheimer+Hypertension necrosis & Full Recovery \\
8 & Female & 66 & &
\end{tabular}

and healed uneventfully. Three of the flaps were rotated $180^{\circ}$ as propeller fashion (Figure 2). Flap dimensions were approximately $2 \times 1-1.5 \mathrm{~cm}$ in size. Total necrosis occured only in one of our patients who continiued using both cigarette and Maras powder in the perioperative period and one patient had partial necrosis (Figure 3). The patient who had total flap loss underwent a cross finger procedure subsequentially and the patient with a partial skin necrosis (Case 4) was managed only with ointment and wet-dressings since she refused another surgey. In case 5, we utilized DAPF as if an anterograde axial flap rather than propeller since we reconstructed extensor tendon along midphalanx and the resultant defect necessitated a longitudinally larger flap (Figure 4). No patients complained of cold intolerance or residual joint contracture. Longest follow-up was 4

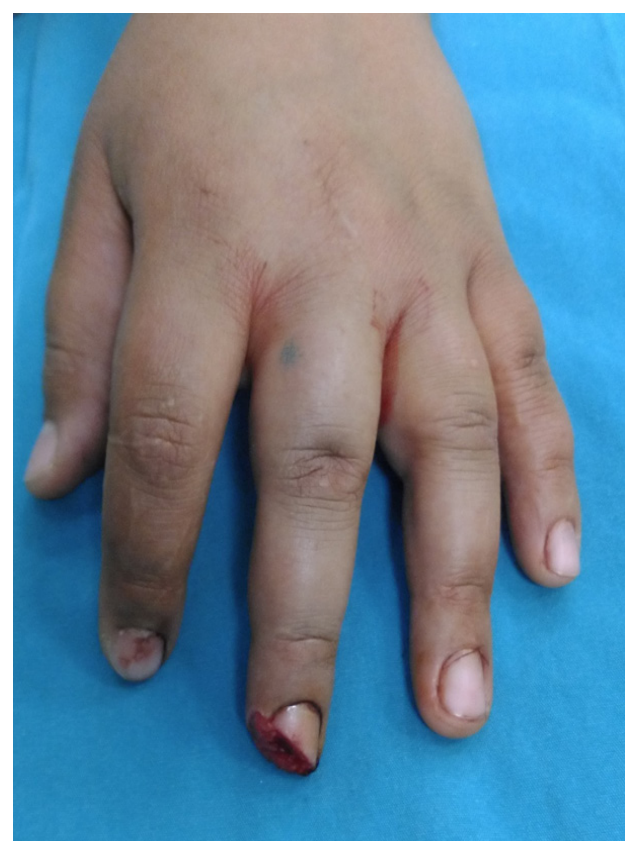

Figure 1a. Oblique distal fingertip defect on middle finger months. One of our patients experienced mild hooked nail deformity. Donor area morbidity of the flaps were minimal and the scar was acceptable (Figure 5). All patients are advised for physical therapy and encouraged for exercises.

\section{DISCUSSION}

Principles of fingertip reconstruction are preserving finger function and length as well as maintaining cosmesis and covering the defect with durable, sensitive and glabrous skin. There are various commonly performed local flaps options for reconstruction of small sized finger tip defects, such as $\mathrm{V}-\mathrm{Y}$ advancement flaps, reverse adipofasial flaps, dorsal metacarpal artery flap, cross finger flap, thenar flap, neurovascular island flaps and reverse-flow homodigital artery flaps, reverse dorsal vein flaps

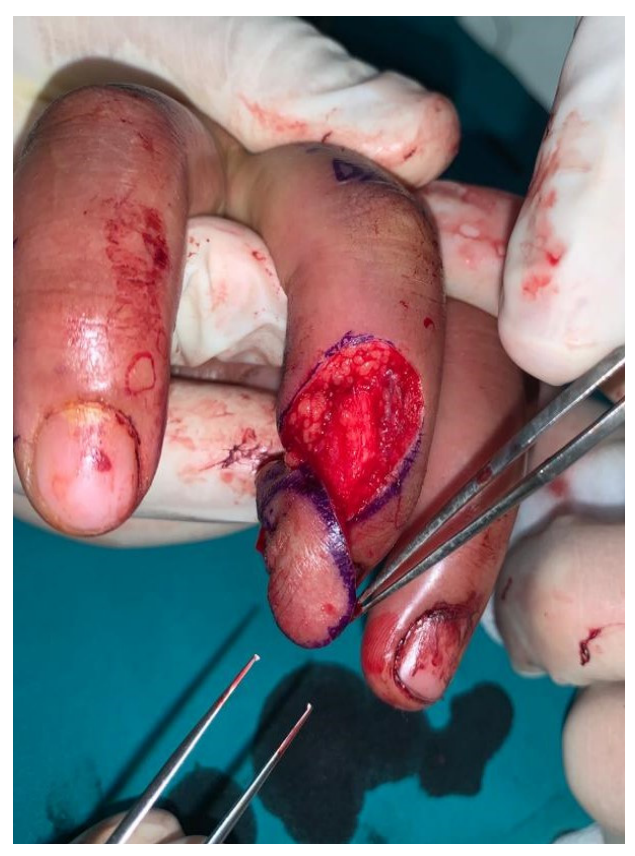

Figure $1 \mathrm{~b}$. DAPF rotated solely on its perforator 


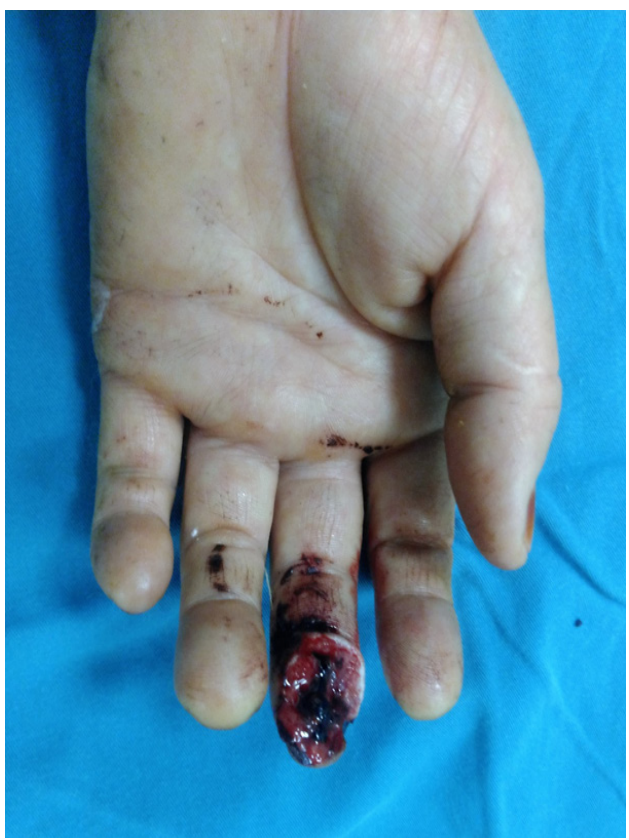

Figure 2a. Volar defect of the middle finger

whereas pedicled interpolation flaps or free flaps harvested from the groin-abdominal region may be required in order to cover larger sized defects $(8,9)$. However, interpolated flap techniques require twostage surgery and may cause stiffness in the joints due to immobilization of the fingers and restriction in range of motion of the fingers. Satisfactory outcomes with good contour and sensory restorations have been reported in the literature using free flaps such as free venous flap, free hemipulp, free thenar flap and free perforator flap of the superficial branch of the radial artery; however advanced microsurgical experience is a must for a fingertip or pulp defect reconstruction using these microsurgical options and duration of operations are quite long compared to conventional ones $(10,11)$. Moreover, these techniques often carry a risk of anastomosis problems, vascular spasm, increased thrombosis rates and high flap loss risk depending on all these factors. Reverseflow homodigital island flaps are also good flaps of choice and can be used in fingertip and pulp defects reconstruction, but a reverse-flow homodigital flap dissection is more invasive, extensive, time consuming and it causes cold intolerance since this technique necessitates the sacrifice of proper digital artery of the finger.

DAPF is a versatile flap that can be easily harvested from the same finger without sacrificing

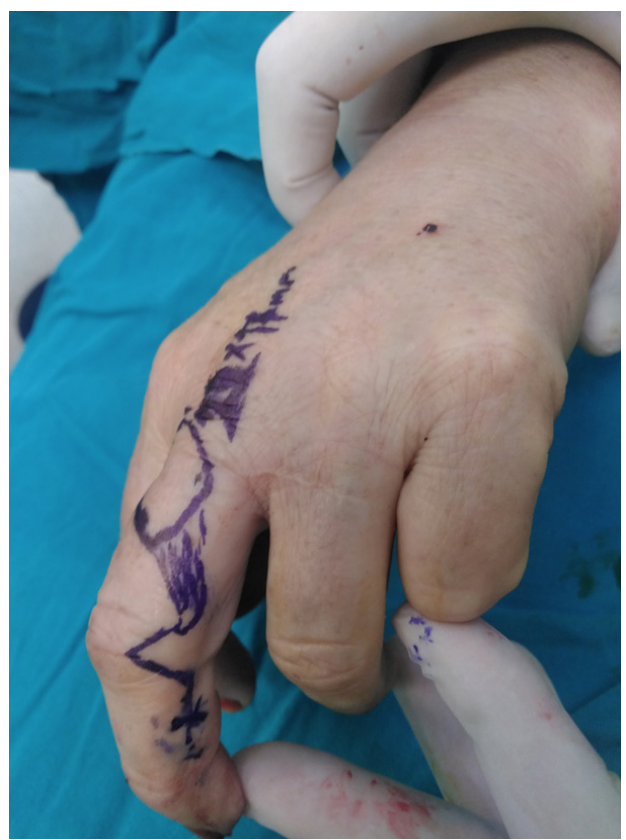

Figure 2b. Flap design

the main artery and nerve (12). The most important advantages of DAPF technique are minimal donor site morbidity, allowing early mobilization, and single-

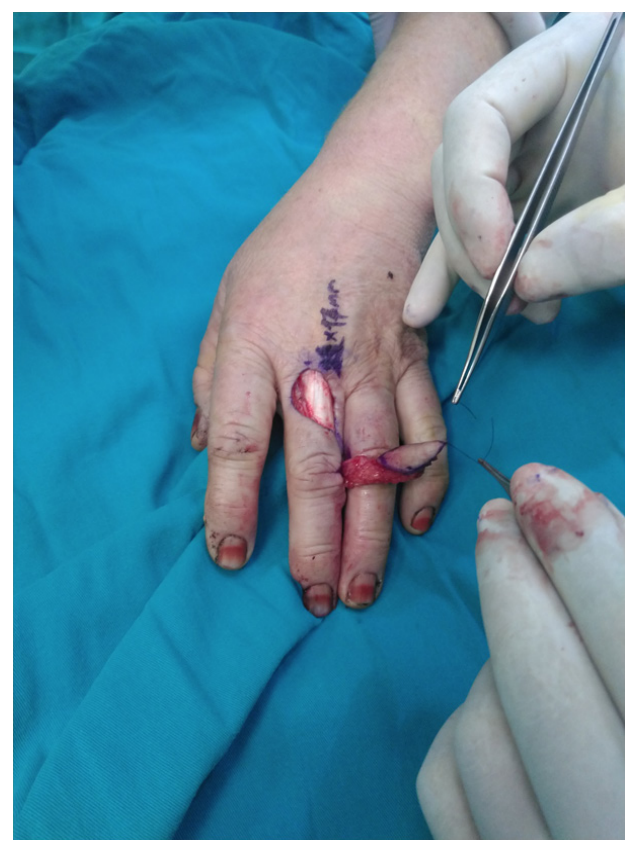

Figure 2c. DAPF, based on ulnar midphalanx located perforator, is raised over paratenon. Note that an adipofascial tissue of 3-4 mm cuff is preserved during flap dissection 


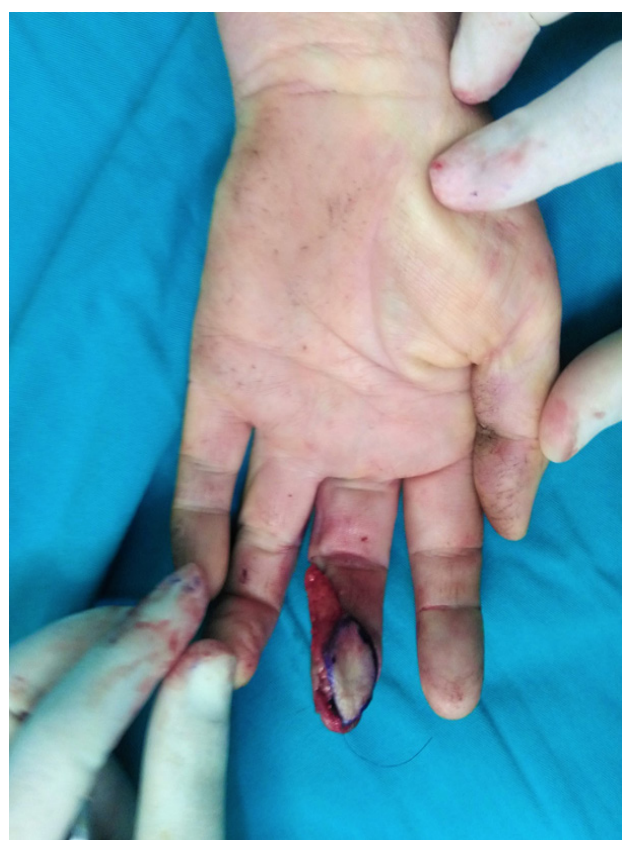

Figure 2 d. Flap is rotated $180^{\circ}$ as propeller and inset to the pulp defect

stage surgery. However, the main disadvantages are the high risk of venous congestion in the early period, the tiny caliber of the perforator, the risk of kinking, twisting or compression when rotated as propeller. Nonetheless, DAPF is not only quite susceptible to the patient's metabolic status (dehydration, hypotension, etc.), medications, smoking habitus and/or similar substance abuse but also contraindicated in patients who have vasospastic disorders like Raynaud,

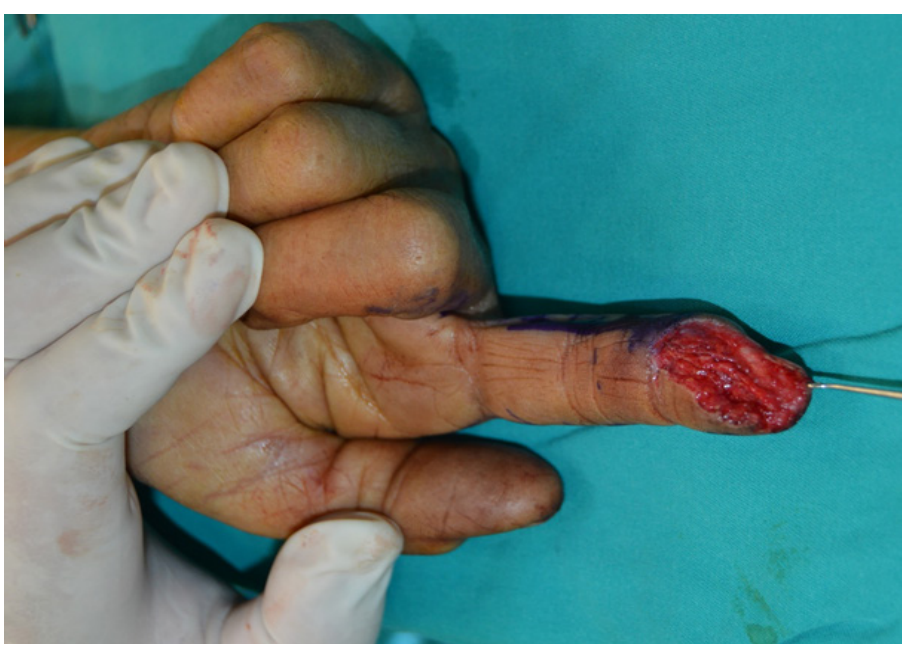

Figure 3a. Index fingertip defect

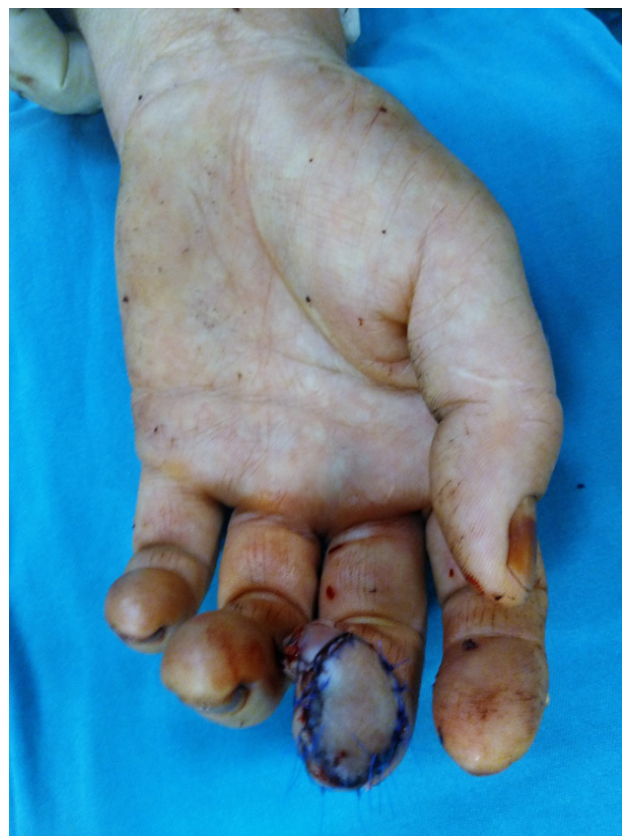

Figure 2e. Immediate postoperative view of the flap is seen. Flap pedicle is not tunneled but rather skin grafted to avoid any compression

diabetes mellitus or smoking ones because of higher rates of flap failure (13). Limited flap size and arterial inflow instability are also other disadvantages of DAPF. Although intraoperative circulation was confirmed in the case resulted with total skin necrosis, it was thought that the development of flap necrosis occured due to vascular spasm and thrombosis induced by smoking and maras powder use known as an oxidant

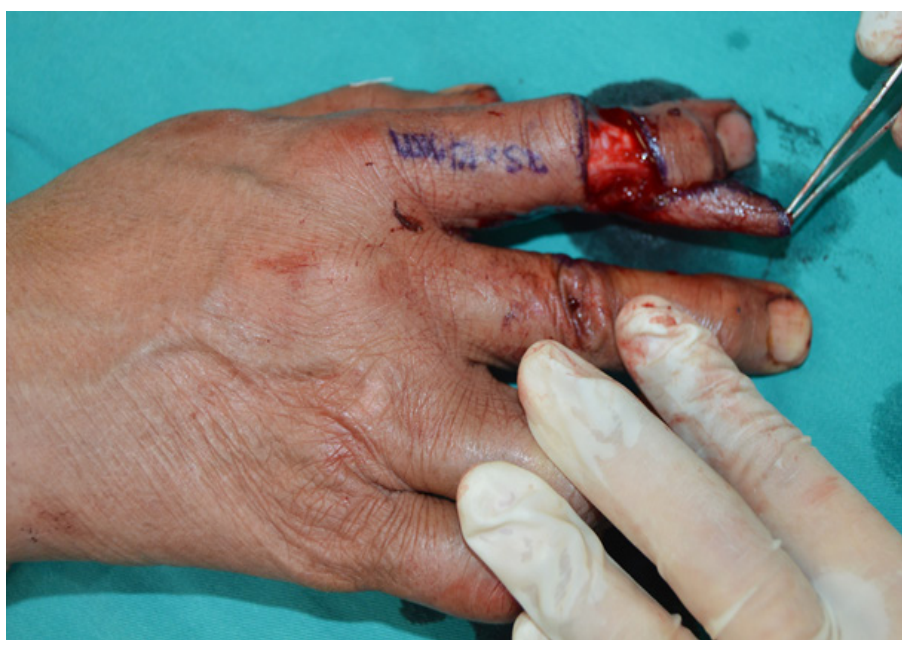

Figure $\mathbf{3 b}$. Flap is raised and rotated 


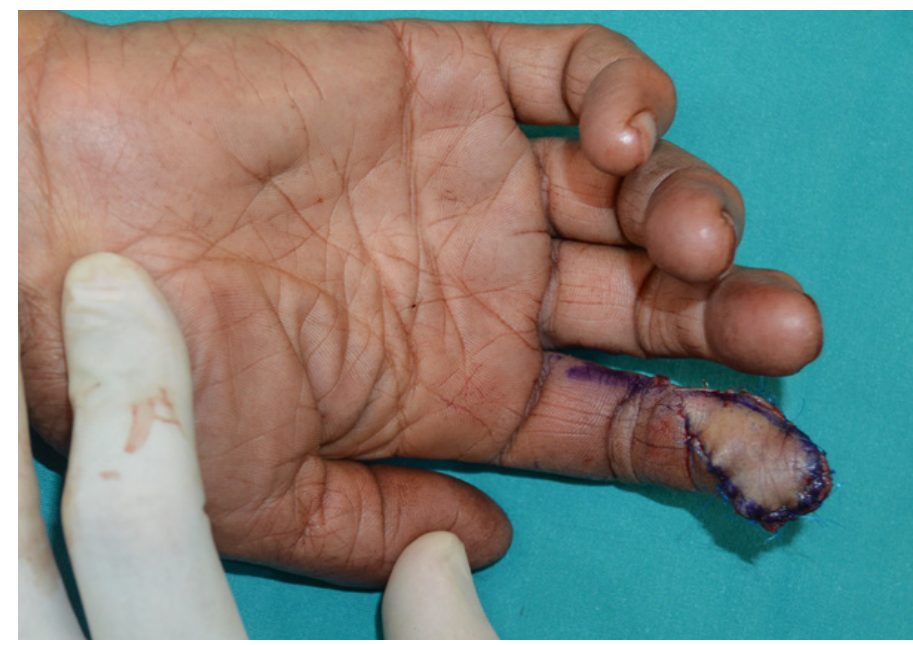

Figure 3c. Final inset of the flap. Note the distal interphalangeal joint is radially deviated

smokeless tobacco agent including 'Nicotiana Rustica Linn'. In the case with partial necrosis, it is estimated that use of immunosuppressants due to rheumatoid arthritis and the radially deviated ankylosis of the distal interphalangeal joint of the patients finger could have further caused a constant postoperative tension and ischemia of the distal portion of the flap. According to our particular practice, if DAPF is planned to be harvested from proximal phalangeal

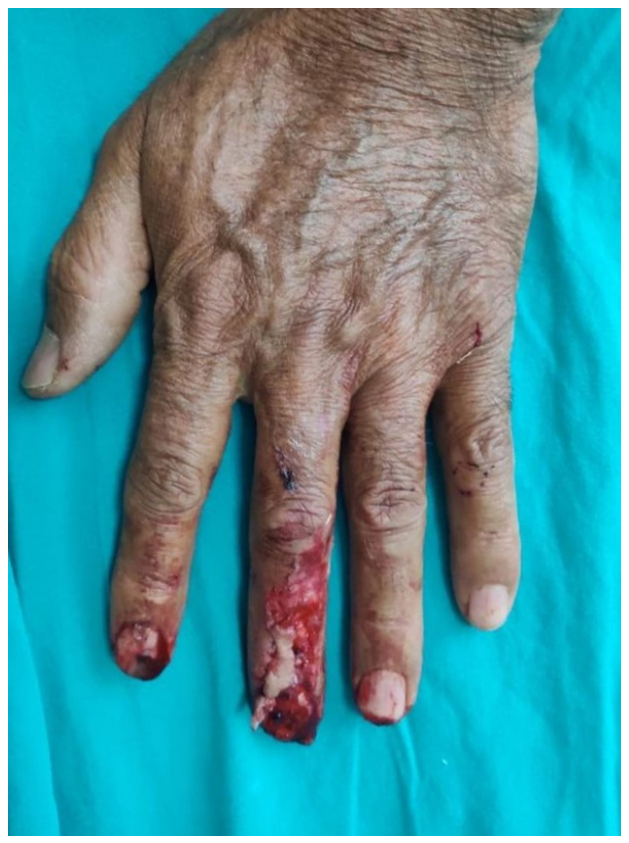

Figure 4a. Fingertip and nailbed defect on middle finger

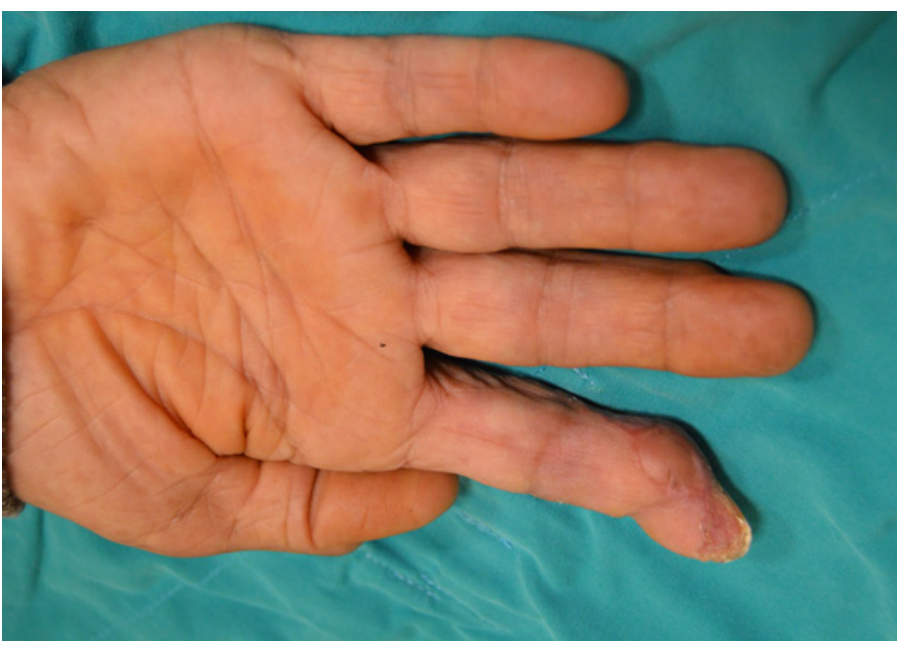

Figure $3 d$. Partial necrosis and secondary healing following debridement

area and used as a propeller flap, skeletonizing the perforator should be avoided because the perforator branches very small calibered and delicate. Therefore, without sufficient soft tissue envelope, vasospasm and/or thrombosis is more likely to occur and impair the flap circulation in a proximally harvested flap. Another important technical issue is that after DAPF harvest, pedicle should be transferred over the radial or ulnar side of the proximal interphalangeal joint to

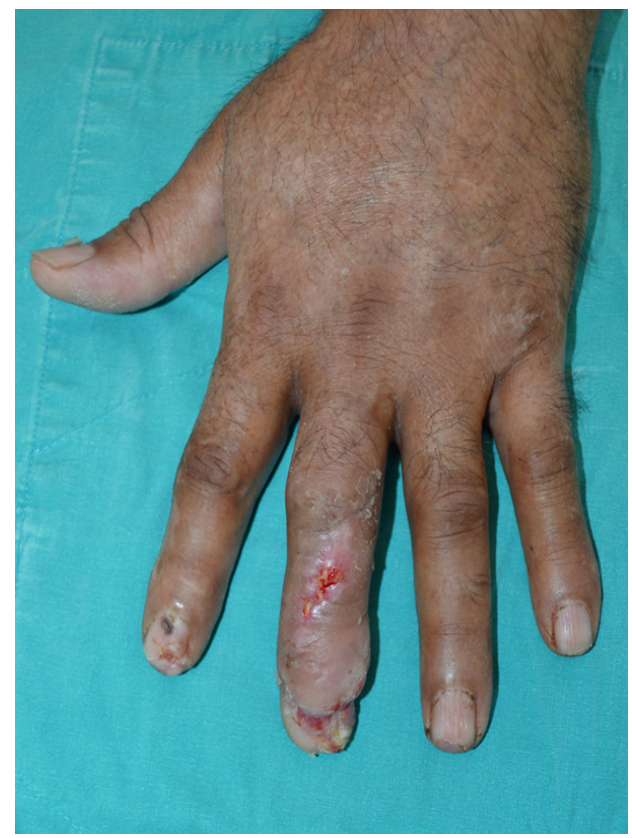

Figure $\mathbf{4 b}$. Postoperative 3 week result is seen 


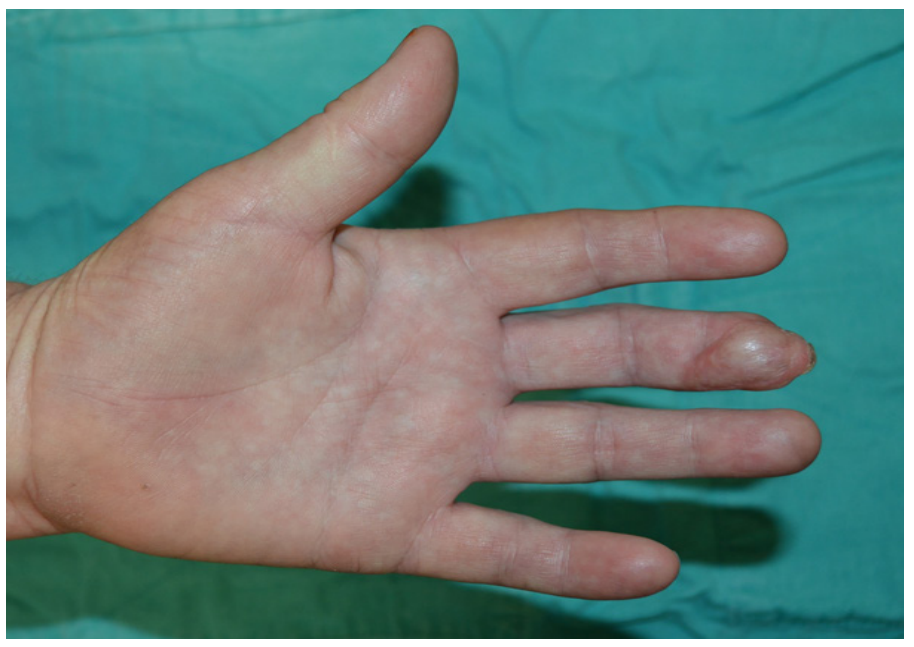

Figure 5a. Satisfactory result on postoperative 4 months (Case 3)

preserve joint movements and prevent any possible contractures. Three-dimensional considerations, orientation and direction of the pulp / fingertip defects should also be considered for surgical decision. DAPF reconstruction seems more suitable for obliquely oriented wounds. That is to say, ulnar sided DAPF harvest and inset seems more physiological for the 2nd and 3rd fingertip defects extending obliquely from proximal-ulnar to distal-radial manner, whereas radial sided DAPF is more physiological for 4th and 5th fingertip defects extending obliquely from proximalradial to distal-ulnar manner since digital artery is often ulnarly dominant in the 2 nd and 3rd finger and

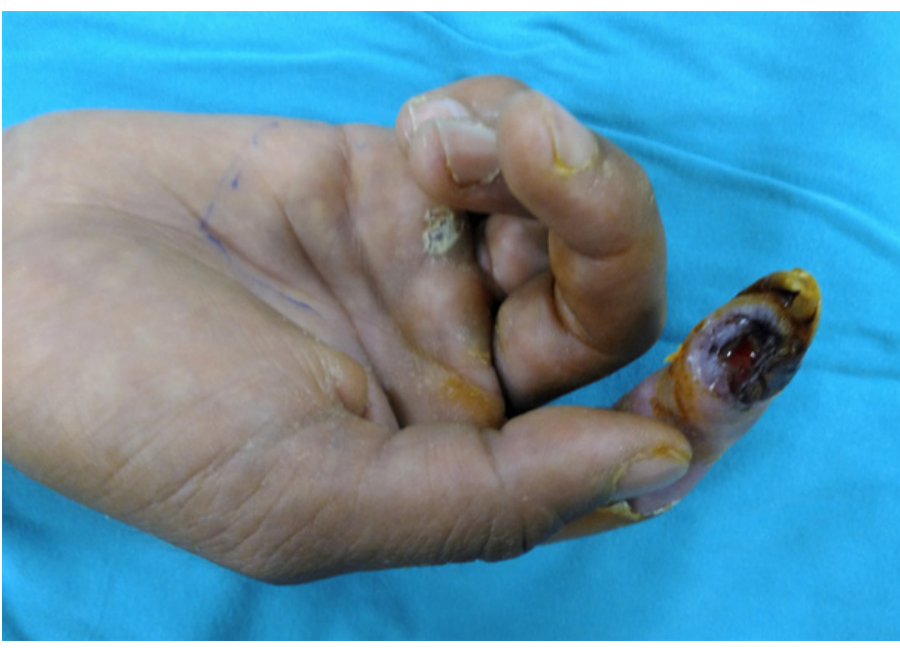

Figure 6a. Index finger soft tissue defect caused by infection

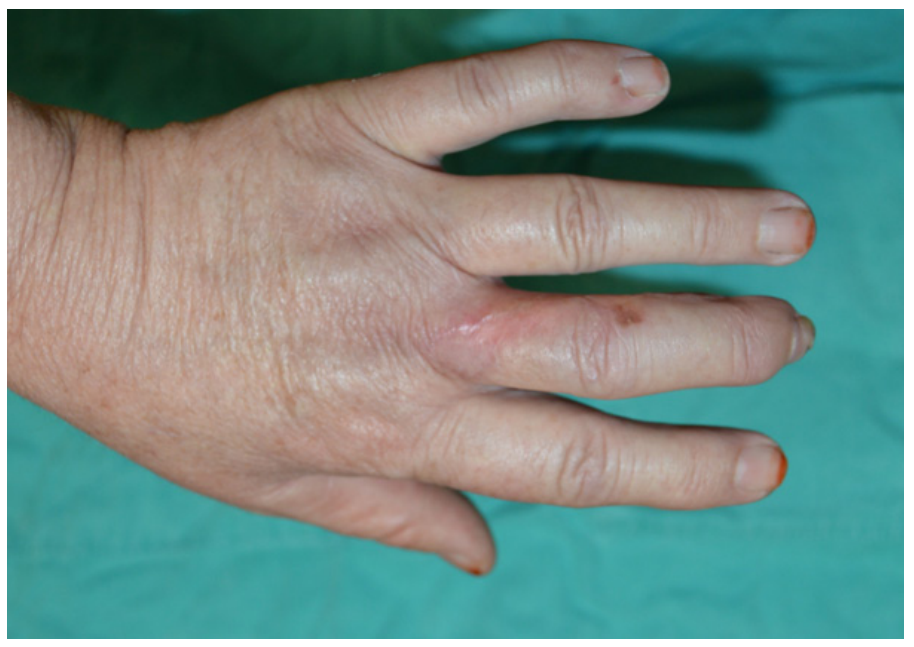

Figure $\mathbf{5 b}$. Donor site morbidity is minimal and the scar is acceptable on long term follow up. Brownish skin lesion on dorsal middle finger is a new burn

radially dominant in 4th and 5th finger. Nevertheless, variations are not uncommon. Few authors suggest identification and confirmation of perforators of proper digital artery, whether on proximal or middle phalanges, by a handheld Doppler USG prior to flap harvest while most authors advocate that perforator localizations are such constant that DAPF can be raised as a free-style fashion $(1,6,7,14)$. In accordance with this, Braga-Silva et al. have demonstrated on fresh human cadavers that digital artery perforators arise at constant locations in the proximal and middle phalanges at a fixed distance from known landmarks

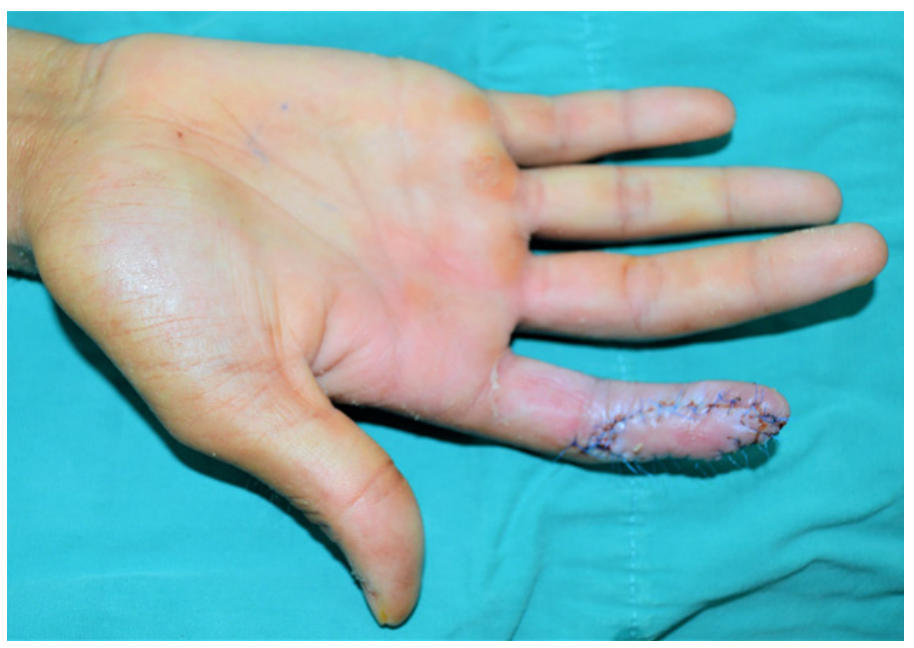

Figure 6b. Postoperative first week photo of reconstruction by DAPF used as an advancement flap 
(15). So, it may be concluded that DAPF has a constant vascular anatomy. It is even so reliable flap that Shen et al. define DAPF as axial flaps rather than free-style flap depending on this reliability (16).

Depending on our limited experience we think that it is more appropiate to harvest DAPF from the middle phalanx if 90-120 degrees arc of rotation is adequate. But if DAPF will be used in a propellar fashion rotating it by 180 degrees, it is more appropriate to harvest the DAPF flap from the proximal phalanx with sufficient adipofascial tissue cuff. Thus, it can provide support for the perforator, reduce the torsion risk of the pedicle and probably the incidence of venous congestion. Moreover, DAPF is also more anatomical for the dorsal fingertip wounds or nail bed defects reconstruction instead of pulp defects since twisting risk of the perforator on its own is lesser. It should also be stated that DAPF can be used to cover the defects on the middle phalanx, distal interphalangeal joint and it can also be used as a transposition and/ or advancement flap based on its perforator if desired (Figure 6).

This study has some limitations that there was no control group and the number of patients was relatively low. Long term follow ups could not be achieved for each individual due to a Covid-19 pandemic and thereby two point discrimination (s2PD) and Semmes-Weinstein monofilament (SWM) tests could not be done properly. We did not perform any digital nerve anastomosis for reinnervation. However, Özcanli reported that sensorial recovery of DAPF is satisfactory in his series as he found no significant difference in the S2PD and SWM tests between who had a branch of the digital nerve and those who did not (17). In contrast, Chen et.al. reported they obtained better Semmes-Weinstein monofilament scores in innervated flaps with dorsal branch of the digital nerve or dorsal digital nerve when compared to noninnervated flaps (18).

\section{CONCLUSION}

In conclusion, DAPF is a reliable and useful flap for fingertip defect reconstructions in non-smoker patients and the patients without serious comorbidities. DAPF is also prone to various modifications and it can be used to cover the defects located on fingertips as well as proximal or midphalangeal located defects. The low donor site morbidity, ease of harvest, single stage operation, preservation of digital artery and rapid recovery are the main advantages that make DAPF beneficial to cover fingertip and pulp defects.
Conflict of interest: Authors declare that there is no conflict of interest between the authors of the article.

Financial conflict of interest: Authors declare that they did not receive any financial support in this study.

Address correspondence to: Alper Ural, Kahramanmaraş Sütçü Imam University, Department of Plastic, Reconstructive and Aesthetic Surgery, Kahramanmaraş, Turkey

E-mail: alper_ural@yahoo.com

Phone number: :+90 5396679506

\section{REFERENCES}

1. GüleçA, Özdemir A, Durgut F, et al. Comparison of innervated digital artery perforator flap versus homodigital reverse flow flap techniques for fingertip reconstruction. J Hand Surg Am 2019;44(9):801.e1-801.e6.

2. Lemmon JA, Janis JE, Rohrich RJ. Soft-tissue injuries of the fingertip: Methods of evaluation and treatment. An algorithmic approach. Plast Reconstr Surg 2008;122:105e-117e.

3. Atasoy E, lokimidis E, Kasdan MI, et al. Reconstruction of the amputated finger defects: Reverse digital artery flap. $\mathrm{Br} \mathrm{J}$ Plast Surg 1970,52A:921-6.

4. Ozcelik B, Ince B. A new technique in fingertip defects including nail lost: Reverse dorsal fascial flap with skin graft. Turk J Plast Surg 2018;26:140-3.

5. Aksoy A, Sir E, Dagdelen D, et al. Reconstruction of finger composite defects with perforator free flap from the superficial palmar branch of radial artery. Turk J Plast Surg 2018;26:449.

6. Koshima I, Urushibara K, Fukuda N, et al. Digital artery perforator flaps for fingertip reconstructions. Plast Reconstr Surg 2006;118(7):1579e1584

7. Mitsunaga N, Mihara M, Koshima I, et al. Digital artery perforator (DAP) flaps: Modifications for fingertip and finger stump reconstruction. J Plast Reconstr Aesthet Surg 2010;63:1312-7.

8. Mutlu OO, Colak O, Dilber A, et al. Complicated fingertip defects: Clinical approach to their reconstruction and the flaps that can be used in emergency settings. Turk J Plast Surg 2019;27:14-8.

9. Ince $B$, Yildirim MEC, Dadaci $M$, et al. A new technique in tamai zone 1 reconstruction: Reverse dorsal terminal vein flap (hat flap). J Hand Microsurg 2019;11(3):140-5.

10. Chi Z, Pafitanis G, Pont LEP, et al. The use of innervated radial artery superficial palmar branch perforator free flap for complex digital injuries reconstruction. J Plast Surg Hand Surg 2018;52(2):111-6.

11. Chen J, Bhatt R, Tang JB. Technical points of 5 free vascularized flaps for the hand repairs. Hand Clin 2017;33(3):443-54.

12. Basat SO, Ugurlu AM, Aydin A, et al. Digital artery perforator flaps: An easy and reliable choice for fingertip amputation reconstruction. Acta Orthop Traumatol Turc 2013;47(4):2504.

13. Lin $\mathrm{YT}$, Loh CYY, Lin $\mathrm{CH}$. Flaps based on perforators of the digital artery. Hand Clin 2020;36(1):57-62.

14. Kostopoulos E, Agiannidis C, Konofaos P, et al. Predictable pattern digital artery perforator flap: An alternative concept in digital reconstruction. Hand (NY) 2018;13(2):244. 
15. Braga-Silva J, Kuyven CR, Fallopa F, et al. An anatomical study of the dorsal cutaneous branches of the digital arteries. J Hand Surg Br 2002;27(6):577-9.

16. Shen XF, Xue MY, Mi JY, et al. Innervated digital artery perforator propeller flap for reconstruction of lateral oblique fingertip defects. J Hand Surg Am 2015;40(7):1382-8.
17. Ozcanli $H$, Cavit A. Innervated digital artery perforator flap: A versatile technique for fingertip reconstruction. J Hand Surg Am 2015;40(12):2352-7.

18. Chen $C$, Tang $P$, Zhang $X$. The dorsal homodigital island flap based on the dorsal branch of the digital artery: A review of 166 cases. Plast Reconstr Surg 2014;133(4):519e-29e 